\title{
Perceptions of Female Heroism from Two Heroines: Portia and Isabel
}

\author{
Zhu Yuanyuan
}

\begin{abstract}
The paper examined similarities and differences in two female characters Shakespeare created: Portia and Isabel in The Merchant of Venice and Measure for Measure respectively. To understand why the two heroines act differently under similar circumstances, the paper compared traits of the characters and ways in achieving female heroism, and it is concluded that disparity in the two characters' reaction occurs as a result of the two's distinctive profiles.
\end{abstract}

Index Terms-Female heroism, Shakespeare, comparative study, Portia, Isabel.

\section{INTRODUCTION}

In Shakespeare's plays, some of them parallel with each other in similar features. The Merchant of Venice and Measure for Measure is one of those pairs. These two plays embody female heroism which "challenges the traditions of male virtue and female monstrosity" (Langis 397) [1] and tell stories of how a character is saved. Also, they incorporate the concept for law and legal interpretation (Daniel 65)[2]. Though the backgrounds and plots are different from each other, these two plays shape two female characters: Portia and Isabel, with their actions against strict and cruel justice, showing the power of female characters. The Merchant of Venice, illustrating the story of how a candid merchant is saved from a mean Jew by a woman, presents the character Portia, the heroine who plays a key role in the case. In this play, Portia uses her eloquence and wisdom successfully reverses the situation and punishes the Jew. Qin (2014) [3] stated that Portia represents one of Shakespeare's female characters who epitomizes women of knowledge and wisdom in an new era. Similarly, in Measure for Measure, the character Isabel weighs the equal significance. She is the one that asks for help and takes part in the whole process of saving her brother. From the definition of female heroism by Langis (397) [4], it is no doubt these two characters are heroines because they challenge male authorities as women, which is quite adverse from the conservative role of the traditional female. However, both fighting against unjust situations, Portia and Isabel share similarities as well as differences in achieving female heroism. This paper, aiming to examine female heroism in the two heroines, discusses how similar and different Portia and Isabel are in demonstrating female heroism.

Before getting into these two characters' similarities and

Manuscript received January 10, 2019; revised March 26, 2019.

The author is with Communication and Network TechnologySchool of Foreign Studies, Northwestern Polytechnical University, China (e-mail: zhuyy0221@163.com). differences in the course of female heroism, it is necessary to understand the characters and their significance in the two plays. Portia, who uses the same strategy the Jew Shylock uses to defeat him and saves her husband's friend, is brave, brilliant, and beautiful. Her bravery can be seen from the scenario when asked for help, Portia made her decision immediately to help rather than worrying about potential risks of her disguise being found out and being punished. She carries out her plan, goes to the court, and speaks in front of the public including the judges and Shylock, the person who will possibly accuse her of cheating and corruption once the truth exposes. Her bravery brings her even further: she does not only speak in public but also speaks in confidence and eloquence. From this, we can see her great courage and action to help friends. Part of Portia's personality shows her brilliance. This can be told from the trick she utilizes to save Antonio. At the very beginning when Portia first meets Shylock, she tries to persuade him to give up the contract in her delicate language: "The quality of mercy is not strained, It droppth as the gentle rain from heaven" (5. 1. 182-83). However, this doesn't work on Shylock, and she is mocked by him: "A Daniel come to judgement! Yea, a Deniel! O wise young judge, how I do hornor thee!" (4. 1. 221-22)[5]. Seeing how stubborn Shylock is, Portia shifts her strategy of persuasion to a bigger trick by guiding him to his own requirement and using the literal meaning of taking a pound of flesh without any drop of blood. Her strategy, firstly emotional persuasion and then logical analysis, reflects her as a brilliant woman. Lastly, Portia is even physically attractive . In 1. 2, it talks about the passionate admiration from her suitors. This gives readers an idea of her enchanting appearance. Even if she is not attractive physically, she must have something special in her, such as the traits mentioned above, that strongly draws the attention of all the princes. One question to note about Portia's characteristics is that is it appropriate to portray her as a clever woman. The main issue here is which term clever or wise, is better. Personally speaking, I agree with the idea that she is clever. To come up with this trick and to lead Shylock into his own logistics trap requires the cleverness in her. To contrast, some scholars argue it is improper to designate Portia as being smart. Jameson states that cleverness implies something commonplace that lacks feeling and reflective powers (42), while Portia is a figure of harmonious blending of energy, reflection, and feeling (43) [6]. To this end, she claims it disparages Portia when she is labeled clever. All of these characteristics added together to be part of her success and consolidates her image as a heroine.

As for Isabel, she comes from a completely different background but is equally gracious and courageous in 
fighting unreasonable laws, making her stand out as another heroine in Shakespeare's plays. Different from Portia who is a wealthy heiress and is pursued by many powerful princes, Isabel is devoted to becoming a nun at Saint Clare and living a peaceful life. Despite the drastically different backgrounds, Isabel strives to save her brother Claudio with all her efforts and eventually brings freedom to him after ups and downs, which suggests her competence of being a heroine. Additionally, Isabel is also a gracious young lady towards whom both Angelo and the Duke feel imposing. They are deeply attracted by her dignity and wisdom. She refuses to compromise to Angelo's vicious idea and furthermore cooperates with the Duke to trap Angelo, during which process she shows great determination as well as independence. Isabel, just like Portia, constitutes one of many heroines Shakespeare created and powerfully displays that woman is empowered to achieve heroism.

From the discussion above, it is obvious that both Portia and Isabel attain female heroism in their own manners; thus, a discussion of similarities and differences in how female heroism is illustrated by them is necessary.

\section{SimilaritiES}

To start with, both of them thwart unjust legal results. The Merchant of Venice, as a legal play, to a large extent, parallels to Measure for Measure (Kornstein 65)[7]. These two plays bring two tough legal dilemmas to the heroines, and they have to confront to the situation where laws restrict their senses of justice as merciful and humane individuals. In Portia's case, it is true Antonio consents Shylock's proposal of cutting one pound of his flesh, and he is supposed to honor his promise according to the contract and the law. In terms of Isabel, her brother indeed violates the regulation and should be punished accordingly. However, finding such sentence neither just nor consistent with their sense of mercy, the two heroines decide to fight for the ones they care, even though it means they will be dealing with the most powerful people in their countries. More than their common acts of rectifying unjust legal decisions are the shared traits of being merciful and courageous. Clear in mind that the legal results could be reasonable and justified regarding what Antonio and Claudio says and does, Portia and Isabel still take actions to defend them in light with their compassion and mercy. Under the circumstance where the law represents the highest and most authoritative force in the country, they choose to speak out for their friend and family, which stems from their warm-hearted and sympathetic personality. Moreover, their deeds of fighting the legal results also indicate their bravery as females. Even today, for example, there is only $36 \%$ of women working in law professions (American Bar Association 2), which shows unequal participation of women in this field[8]. Imagine during Shakespeare's era when women were even more depressed, two fair young ladies step out of their comfort zone and speak up in court to secure the people they care for, how much courage it requires to do so. Through their defeat of the unreasonable judgement, we can see Portia and Isabel are not only heroines but also the altruistic heroines. The female heroism in them is not saving people with strength but with mercy and sentiment. Additionally, it suggests the compassion as an element in female heroism.

Another thing Portia and Isabel have in common is the eloquence when pleading for mercy. This can be traced when they try to reason with Shylock and Angelo respectively. As mentioned above, before Portia finds it effortless to reason Shylock to spare Antonio, she initially appeals (4. 1. 182-20) [9]:

The quality of mercy is not strained; It droppth as the gentle rain from heaven

Upon the place beneath. It is twice blessed;

It blesseth him that gives and him that takes...

His scepter shows the force of temporal power, the attribute to awe and majesty...

But mercy is above this sceptered sway...

Therefore, Jew, though justice be the plea, consider this:

That in the course of justice none of us should see salvation.

We do pray for mercy, and that same prayer doth teach us all to render the deeds of mercy.

This speech is very persuasive to change one's behavior. It does not only explain what is mercy but identifies how valuable it is. To make her speech more convincing, she compares the rules with mercy, drawing the conclusion that though rules and power are imperative, mercy still outweighs them. Likewise, Isabel is endowed with the same merit. When she first meets Angelo, she pleads: "I have a brother is condemned to die. I do beseech you, let it be his fault, and not my brother." (2. 2. 34-36) [9] from which we can tell she shifts the receiver of the punishment from her brother to his behaviors. One thing to note about their eloquence is that though they excel at using the power of language to persuade, the manner is slightly different to acquire the outcome. Portia seems to embrace rhetoric devices and emotional responses. For instance, she compares mercy to gentle rains, touching readers with the beauty of her language. Differently, Portia prefers persuading by reasoning. It is apparent from her speech that she is playing a logic game with Angelo. The differences between their way of persuasion reflect two of the Aristotle's three modes of persuasion: pathos and logos. Portia's eloquence style fits the former concept which refers to the persuasion with emotions, whereas Isabel's matches the latter one which emphasizes the role of logic in persuasions. Slightly differing from each other, Portia and Isabel's eloquence still stands as a similar quality they share. Eloquence is one of the skills that help them to achieve heroism.

In addition to the two points listed above, it is also noticeable that both Portia and Isabel demonstrate strong and independent female images. This manifests in Portia's idea of disguising herself as a man and going to the court and Isabel's firm rejection of sacrificing her virginity to trade for her brother. This common characteristic further implies their qualification as heroines and independence as one of the themes of female heroism.

\section{DIFFERENCES}

Portia and Isabel's talents in achieving female heroism are closely aligned, but there are some features that help to 
distinguish them when perceiving the female heroism in them. Firstly, they have different attitudes and reactions when asked to manage the emergent situations. For Portia, she comes up with a plan right after she knows the situation, and at the same time commands her servant to work on it: "Now, Balthasar, as I have found you thee honest-true... Take this letter, and use thou all th' endeavor of a man in speed to Pauda...into my cousin's hands..." (3. 4. 45-50) [9]. Her response is instant and decisive. To contrast, Isabel is more hesitating after knowing her brother's situation: “Alas, what poor ability's in me to do him good?" (2. 1. 75-76) [9]. This sentence indicates that compared with Portia, Isabel lacks confidence and decisiveness to respond to emergent issues. To analyze, the backgrounds of the two characters can address the differences. On the one hand, Portia, a heiress, is brought up in an environment where she is adored, pampered and praised quite often; on the other hand, Isabel is a pious lady who is going to become a nun and live like a recluse, which builds her humble and introvert personality and makes her view herself inferior to others. From this difference, we can see heroines with adverse personality may perform female heroism differently, in other words, the personality of heroines influenced by their backgrounds are in line with the styles of them when pursuing female heroism.

The difference also exists in identities the two heroines have when appealing justice. More specifically, Portia dresses up as a man to deceive the public, and her performance absolutely fits her fake identity. As Dusinberre (1996) stated: "Shakespeare's heroines integrate their experiences as men with their feeling as women" (265) [10]. From Portia's speeches, it is not easy to detect the trace of a woman. She speaks in confidence and, step by step, leads Shylock to her trap. In terms of Isabel, she does not make any changes to her identity; moreover, she invites advice from the Duke and does not carry out the entire plan by herself. This again, suggests the different ways of them in coping with emergencies. Portia is more inclusive and independent in devising the plan, whereas Isabel is constrained to limited ideas. However, this doesn't suggest Portia's way is better than Isabel's. Changing identity or not is only the means to achieve the heroic outcome considering they both save the person in the end. Also, this brings the idea that heroines only work to the best when they find their own ways and styles of practicing female heroism.

Last but not least, there is the difference in the consistency of heroines' words with their deeds. Examining this on Portia, it is no difficulty finding hers is deviating. She gives the wonderful speech of how people should act in mercy but fails to conduct her notion when it comes to punishing Shylock. As can be seen from Portia's speech pleading for mercy, she employs exquisite language to talk about how one should be merciful, while she does not show any mercy or sympathy to Shylock when winning the case. Among her punishments for Shylock, neither one exerts mercy in taking all his property, sentencing him to death, and converting his religion. To this end, Kornstein comments that instead of being an "exquisite heroine", Portia is more like an "eloquent mouthpiece" (77) [11]. Oppositely, Isabel clarifies what she won't do but still conducts it. Expecting her brother to value her virginity more than his physical death, Isabel gets upset and tells him she would not save him: "Be ready, Claudio, for your death tomorrow." (3. 1. 107)[12]. However, saving Claudio remains as her priority, and she channels considerable efforts in this process by discussing with the friar and carrying out their plan. From the different inconsistency between Portia and Isabel's words and deeds, it can be concluded that some heroines use various strategies to achieve female heroism no matter it is deeply from the bottom of their hearts or not. Also, we can tell not every heroine in Shakespeare's plays enjoys perfect personality, but to some degree, they still succeed in acquiring female heroism for the nature of being humans.

\section{DISCUSSION}

Both Portia and Isabel demonstrate what strong heroines are like in that era, some even view them as "perfect" demo of females free from male's influences and restrictions, but is that so?

For one side, they showcase powerful and "perfect" female images. Yaoxin (1990) said in his article that Portia stands out as a character of feminism that Shakespeare created[13]. She disguises others in male identity and forces the Jew to take the punishment, which derails from the traditional expectations to women. Also, Portia plays her trick to marry the one she's willing to rather than the one arranged by her father. She "manages to play by society's rules (mostly) while having a lot of fun twisting said rules to her own advantage" (Shmoop Editorial Team 2008) [14], suggesting her unique female character compared to those who obediently following the rule. This also applies for Isabel, a girl of integrity, sufficiently independent to save his brother. It is no exaggerating to say they achieve their goals with little man's influence. In addition to their success in saving their loved ones, they are endowed with attractive appearance and personality. To some extent, they do set an example of "perfect" heroines.

For the other side, they don't fit the idea of "perfect" heroines because they are subject to man's interference and influence. Though having managed to save the characters from unjust laws, Portia and Isabel could not have made it with male characters' help. In Portia's case, only had she acquired recommendation letter from her cousin and consent from the judge that she dares to venture to dress like a man and rescue Antonio; the influence of males can also be seen in Portia's submitting to her fiance by saying she would like to give her gentle heart to him and let him guide and dominate it, which again implies she's too weak to posses a "perfect" personality for a heroine. Likewise, Isabel saves Claudio not entirely out of her individual efforts. After getting her knees down and giving a touching speech, it is the Duke that has the final say on how to deal with Claudio. Man's power also steps in when Isabel hesitates and silences facing the Duke's proposal regarding her previous determination to become a nun. Just as Shmoop Editorial Team (2008) writes: “Isabella comes off as an uptight ice-maiden. For others, Isabella is a sympathetic victim who is placed in an impossible position.'"[15], it is true Isabel exemplifies top qualities as a heroine but also shows subordination to men. In this sense, 
Portia and Isabel hardly hit the "perfect" heroines title but appear to be more subject to a male dominated world.

\section{CONCLUSION}

All in all, even though both Portia and Isabel exhibit female heroism, their styles, personalities, and means vary, which implies the diverse paths to achieve female heroism in Shakespeare's plays. They might be powerful heroines but not "perfect" heroines. Portia and Isabel, intelligent, affectionate, and courageous, showcase the power in women to be heroines and motivate women in today's world to discover themselves and chase after their dreams.

\section{REFERENCES}

[1] L. Unhae, "Virtuous viragos: Female female heroism and ethical action in Shakespearean drama," Literature Compass, vol. 7, no. 6, pp 397-411, May 2017.

[2] D. Kornstein, Kill All the Lawyers? Shakespeare's Legal Appeal, University of Nebraska Press, 2005.

[3] M. Qin, "The wake up of wise females by Shakespeare--The Merchant of Venice," Aba Teacher's University, vol. 31, no. 3, pp. 79-81, 2014

[4] L. Unhae, "Virtuous viragos: Female female heroism and ethical action in Shakespearean drama," Literature Compass, vol. 7, no. 6 pp 397-411, May 2017.

[5] S. Orgel and A. R. Braunmuller, The Complete Pelican Shakespeare, Penguin Books, 2002.

[6] J. Anna, Shakespeare's Heroines: Characteristics of Women, Moral, Poetical, and Historical, AMS Press, 1967.
[7] D. Kornstein, Kill All the Lawyers? Shakespeare's Legal Appeal, University of Nebraska Press, 2005.

[8] American Bar Association-Commission on Women in the Profession. (2017). A current glance at women in the law. [Online]. Available: http://www.americanbar.org/content/dam/aba/marketing/women/curre nt_glance_statistics_january2017.authcheckdam.pdf

[9] S. Orgel and A. R. Braunmuller, The Complete Pelican Shakespeare, Penguin Books, 2002.

[10] D. Juliet, Shakespeare and the Nature of Women, 2nd ed., St. Martin's Press, 1996.

[11] D. Kornstein, Kill All the Lawyers? Shakespeare's Legal Appeal, University of Nebraska Press, 2005.

[12] S. Orgel and A. R. Braunmuller, The Complete Pelican Shakespeare, Penguin Books, 2002.

[13] C. Yaoxin, A Study of American Literture, Tijian: Nankai University, 1990.

[14] Shmoop Editorial Team, Portia in The Merchant of Venice, Shmoop. Shmoop University, Inc., Nov. 2008.

[15] Shmoop Editorial Team, Isabella in Measure for Measure, Shmoop. Shmoop University, Inc., 11 Nov. 2008.

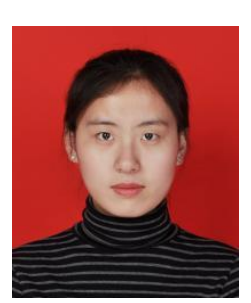

Yuanyuan Zhu was born on February 21, 1995 in Tongchuan, Shaanxi Province in China. She obtained bachelor's degree in English from Xi'an International Studies University in 2017 and is currently studying interpreting at Northwestern Polytechnical University (NPU).

She used to work at multiple English institutions to teach English to young kids and adults. She also teaches Chinese culture to international students at NPU and works as a classroom assistant at Queen Mary University of London Engineering School, NPU. 